\title{
AKHLAK PERGAULAN DALAM ISLAM
}

\author{
Ni'matul Hasanah', Leny Nuraeni ${ }^{2}$ Jumliadi $^{3}$ \\ ${ }^{1}$ Sekolah Tinggi Agama Islam ( STAI ) Darul Dakwah Wal-Irsyad (DDI) Kota Makassar, Indonesia \\ Email: nimatulhasanah2006@gmail.com \\ ${ }^{2}$ Sekolah Tinggi Agama Islam ( STAI ) Darul Dakwah Wal-Irsyad (DDI) Kota Makassar, Indonesia \\ Email: lenynuraeni630@gmail.com \\ ${ }^{3}$ Sekolah Tinggi Agama Islam ( STAI) Darul Dakwah Wal-Irsyad (DDI) Kota Makassar, Indonesia \\ Email: jumliadirajab87@gmail.com
}

\begin{abstract}
ABSTRAK
Pergaulan merupakan suatu fitrah bagi manusia karena sesungguhnya manusia merupakan makhluk sosial. Manusia memiliki sifat tolong menolong dan saling memerlukan. Sebenarnya dalam Al-qur'an telah dijelaskan hubungan antara lelaki dan perempuan, hubungan sesama jenis, hubungan antara anak dan orang tua, hubungan antara muslim dan non-muslim. Langakah pertama dalam pergaulan adalah perkenalan, inilah tujuan allah menjadikan manusia bersuku-suku, berbangsa-bangsa, terdiri daripada lelaki dan perempuan. Perkenalan harus segara dilakukan dengan orang yang belum dikenali, karena hal itu lebih cepat dapat menguatkan tali persaudaraan dan membuka pebualan.

Kata Kunci: Akhlak,Pergaulan,Dalam Islam
\end{abstract}

\section{A. PENDAHULUAN}

Secara Etimologi, Perkataan "Akhlak" berasal dari bahasa Arab jama'dari bentuk mufradnya "khuluqun" dengan budi pekerti, perangai, tingkah laku atau tabiat. Akhlak itu terbagi 2 yaitu (Akhlak Mahmuda) dan (Akhlak Mazmumah). Sekiranya pergaulan itu berdasarkan kepada tujuan mendesak ataupun keperluan, maka dibolehkan. Walau bagaimanapun, dalam masa yang sama, perlu menjaga batas-batas pergaulan sebagaimana yang telah digariskan Islam. Allah SWT berfirman dalam surat Al-Isra ayat 32. "Dan janganlah kamu mendekati zina, sesungguhnya zina itu adalah suatu perbuatan yang keji dan suatu jalan yang buruk. Dalam tersebut Allah swt telah jelas melarang manusia untuk mendekati zina karena zina merupakan perbuatan yang keji.

Akhlak menurut Imam Gazali adalah sifat yang tertanam dalam jiwa yang menimbulkan perbuatan-perbuatan dengan gampang dan mudah tanpa memerlukan pemikiran terlebih dahulu. Sedangkan

Akhlak menurut Ibrahim Anis adalah sifat yang tertanam di dalam jiwa dan terdapat macam-macam perbuatan tanpa membutuhkan pertimbangan terlebih dahulu. 


\section{B. PEMBAHASAN}

\section{Pengertian Aqidah}

Secara bahasa Aqidah berasal dari kata 'aqoda, yaitu ya'qidu, 'aqdan, 'itiqoodan yaitu: kepercayaan hati atau keyakinan. Pengertian Aqidah secara terminologi atau istilah dikemukakan oleh para ahli diantaranya:

Menurut Imam Al- Ghazali menyatakan, apabila telah tumbuh pada jiwa seorang muslim, maka tertanamlah dalam jiwanya rasa bahwa Allah sajalah yang paling berkuasa, segala wujud yang ada ini hanyalah makhluk belaka.

Menurut Abdullah Azzam, Aqidah adalah iman dengan semua rukunrukunnya yang enam. Maksudnya adalah pengertian iman yaitu: keyakinan atau kepercayaan akan adanya Allah SWT, malaikat-malaikat-nya, kitabkitabnya, Nabi-nabinya, hari kebangkitan dan Qadha dan Qadarnya.

\section{Akhlak}

Akhlak berasal dari bahasa arab dar i kata (khuluk) yang berarti tingkah laku, tabiat atau perangai. Secara istilah, akhlak yaitu sifat yang memiliki seseorang, telah melekat dan biasanya akan tercermin dari perilaku orang tersebut.

Pengertian akhlak dapat ditinjau dari dua pengertian secara etimologis dan terminologis . secara etimologis, kata akhlak berasal dari bahasa Arab alakhlaq, kata ini merupakan bentuk jamak dari al-khuluq yang berarti budi pekerti atau watak. Secara linguistic (kebahasaan) kata akhlak merupakan isim jamid atau isim ghoir mustaq yaitu isim yang tidak mempunyai akar kata, melainkan kata tersebut memang begitu adanya, kata akhlak adalah jamak dari kata Khuluqun/khuluq yang artinya sama dengan arti kata akhlak. Pengertian secara terminologis akhlak adalah kehendak yang dibiasakan, dalam pertian jikakehendak itu membiasakan sesuatu maka kebiasaan itu dinamakan akhlak.

Pada dasarnya hukum bermua'malah dalam Islam adalah Mubah (boleh). Dalam kehidupan sosial pun manusia takkan lepas dari hal bersosialisasi dengan orang lain. 
Beberapa hal yang dapat dianjurkan dalam bergaul dengan orang lain:

a. Lemah lembut terhadap orang lain

b. Tersenyum

c. Kasih sayang

d. Memberi salam

e. Jabat tangan (dengan mahramnya)

f. Mempermudah atau saling membantu orang lain

g. Menolong orangg lain

h. Jangan sombong dengan orang lain

i. Melakukan perkenalan

Langkah pertama dalam pergaulan adalah perkenalan. Inilah tujuan Allah menjadikan manusia bersuku-suku, berbangsa-bangsa, terdiri daripada lelaki dan perempuan. Perkenalan harus segera dilakukan dengan orang yang belum dikenali, karena hal itu lebih cepat dan menguatkan tali persaudaraan dan membuka perbualan.perumusan pengertian "Akhlak" timbul sebagai media yang memungkingkan adanya hubungan baik antara khalik dengan makhluk dengan makhluk lain. Perkataan ini telah tercantum dalam Al-qur'an.

Akhlak terpuji (Akhlakul Mahmudah)

Akhlak terpuji yaitu golongan akhlak yang seharusnya dimiliki oleh seorang muslim. Akhlakul Mahmudah meliputi sifat sabar, jujur, rendah hati, sopan dan santun.

Sedangkan Akhlak tercela (Akhlakul Mazmumah) Akhlak tercela yaitu golongan akhlak atau tindakan buruk yang harus dihindari oleh setiap manusia.Akhlakul mazmumahyaitu sifat sombong, tamak, hasad, takabur dan ghibah. Adapun tujuan akhlak antara lain: 

a. Kemajuan rohani
b. Penuntun kebaikan
c. Kesempurnaan iamn
d. Keutamaan di hari kemudian
e. Kebutuhan pokok dalam keluarga
f. Untuk membina kerukunan antar umat bangsa
g. Peranan akhlak dalam masyarakat

\section{Pergaulan Dalam Islam}

Pergaulan yang baik ialah melaksanakan pergaulan menurut norma-norma kemasyarakatan yang tidak bertentangan dengan hukum syara, serta memenuhi segala hak yang berhak mendapatkannya masing-masing menurut kadarnya. Agama Islam menyeru dan mengajak kaum muslimin.karena dengan pergaulan kita saling berhubungan melakukkan pergaulan, kita saling berhubungan mengadakan pendekatan satu sama lain, kita bisa saling mengisi dalam kebutuhan serta dapat mencapai sesuatu yang berguna untuk kemaslahatan masyarakat yang adil dan makmur serta berakhlaqul karimah.

Islam adalah agama yang dilandasi persatuan dan kasih sayang, kecenderungan untuk saling mengenal diantara sesama manusia dalam hidup dan kehidupannya, meruppakan ajaran Islam yang sangat ditekankan , Islam bukan mempunyai garis hidup yang konret dalam batasan-batasan hidup bermasyarat

4. Pergaulan antara Laki-Laki dan Perempuan

Hendaknya setiap muslim, menjaga pandangan matanya dari melihat lawan jenis secara berlebihan, setiap muslim menjaga auratnya masing-masing dengan cara berpakaian islam agar terhindar dari fitnah. 
Batasan aurat bersama bukan mahram (ajnaib).

a. Lelaki antara pusat ke lutut

b. Wanita seluruh badan kecuali muka dan telapak tangan

Berpakaian sopan yaitu tidak tipis sehingaa menampakkan warna kulit, tidak ketat sehingga menampakkan bentuk badan dan tudung melebihi paras dada

Hindarilah bersentuhan kulit dengan lawan jenis, termasuk berjabatan tangan sebagaimana yang dicontohkan oleh Nabi SAW, "sesungguhnya aku tidak berjabatan tangan dengan wanita."

Pergaulan anatara muda mudi ( lawan jenis) menurut syari'at islam adalah pergaulan yang dilakukan seorang muda mudi dalam kehidupan sehari-hari atau berinteraksi terhadap sesama manusia yang didasarkan kepada AlQur'an dan Hadist, yaitu sebagai contoh seseorang laki-laki berta'aruf kepada seorang perempuan. Dalam konteks hubungan antara laki-laki dan perempuanyang bukan mahram, istilah tak kenal maka tak sayang adalah awal dari terjadinya hubungan saling mencintai.

5. Pergaulan seorang muslim dengan non muslim

Islam tidak melarang umatnya bergaul dengan kaum non muslim. Hanya saja, dalam pergaulan Islam telah memberikan adab-adabnya baik dengan sesama muslim dengan non muslim. Dalam perkara umum sosial kita tetap menjalin hubungan yang baik dengan non muslim walaupun berlainan agama dengan pasangan. Nabi sendiri pernah berdiri ketika iringan jenazah non muslim melewati nabi. Dalam masalah aqidah dan ubudiyah, kita tidak mengucapkan dan menjawab salam kepada mereka. Muslim memberi kesempatan kepada non muslim untuk mendengar kalamullah, bahkan memberi kesempatan belajar bersama tentang islam, muslim juga senantiasa memelihara hubungan baik, perdamaian, tidak merugikan pihak lain seperti manganiaya, curang, mencuri harta, serta menghianati amanah kesepakatan non muslim. 
Allah tidak melarang kamu untuk berbuat baik dan berlaku adil terhadap orang orang yang tiada memerangimu, Allah SWT mencintai dan memerintahkan umatnya berbuat baik dan berlaku adil kepada orang kafir atau ( non muslim) yang tidak memerangi dan mengusir umat Islam dari tempat tinggalnya. Yang ditekankan Islam dalam persahabatan dengan orang kafir adalah tidak menjadikan mereka orang terdekat yang dicintai dan tidak menjadikan mereka orang kepercayaan yang melebihi mukmin.

\section{Pergaulan dengan sebaya}

Teman sebaya atau teman karib adalah orang-orang atau teman yang usianya tidak terpaut jauh dengan kita baik sama maupun lebih muda. Dalam pergaulan dengan teman sebaya kita harus senantiasa berbuat baik dan mengutamakan akhlak mulia. Mengucapkan salam setiap bertemu dengan teman sebaya dan sesama muslim, mengucapkan salam hukumnya sunnah bagi umat islam dan menjawab salam hukumnya wajib

Saling mengerti serta memahami kebaikan dan kekurangan masing-masing dan menghindari segala macam jenis perselisihan. Teman sebaya hendaknya saling tolong menolong dalam hal kebaikan dan menolong teman sebaya yang sedang dalam kesusahan tentunya sangat dicintai Allah SWT. Senantiasa menjaga teman dari pengaruh buruk atau gangguan orang lain, memberikan nasihat kebaikan satu sma lain, mendaimaikan teman jika ada yang berselisih, mendoakan teman agar mereka senantiasa berada dalam kebaikan.

Adab adalah norma atau aturan mengenai sopan santun yang didasarkan atas aturan agama, terutama Agama Islam, norma tentang adab ini digunakan dalam pergaulan antar manusia, antar tetangga, dan antar kaum. Sebutan orang beradab sesungguhnya berarti bahwa oran itu mengetahui aturan tentan adab atauu sopan santun yang ditentukan dalam Agam Islam. Namun, dalam perkembangannya, kata beradab dan tidak beradab dikaitkan dari segi kesopanan. Dalam mencari teman kita harus selektif dan hati-hati. Tidak semua orang harus kita jadikan teman, dan setelah kita mendapatkannya, kita tidaklah asal-asalan didalam bergaul dengannya. 
a. Carilah teman yang baik

Dalam mencari teman, carilah teman yang selalu mengingatkan kita dalam kebaikan yang bisa menuntun kita ke jalan yang baik

b. Saling menghormati dan menghargai

Kaum muslim adalah seluruhnya sama, yang membedakkan mereka hanyalah kadariman dan takwa masing-masing. Namun, antara satu dengan yang lainnya haruslah menciptakan rasa hormat dan saling menghargai antara satu dengan yang lain. Yang muda menghormati yang tua dan yang tua menyayangi yang muda, jika terdapat perbedaan pendapat antara satu dengan yang lainnya, hendaknya disikapi dengan rasa lapan dada dan saling menghargai pendapat.

c. Menyikapi teman sebagai saudara

Karena umat Muslim itu ibarat satu tubuh, jika ada oragan tubuh kita yang tersakiti maka anggota yang lain juga ikut merasakannya.

Sebagaimana hendaknya kaum muslimin jika saudaranya yang satu iman sedang tersakiti, maka kaum muslimin yang akan merasakan sakit tersebut. Jika teman kita sedang kesulitan maka kita pun harus membantunya, dan selalu menemaninya baik dikala susah maupun senang.

\section{Pergaulan dengan orang yang lebih tua}

sebagai umat Islam kita harus menghormati dan memuliakan orang yang lebih tua dari kta, karena yang demikian itu merupakan ajaran akhlak islam yang paling ditekankan sebagai sikap terpuji yang mempunyai nilai kewajiban ilahi. Terutama kepada orang yang paling dekat dan paling berjasa dengan kita, seperti orang tua kita sendiri, yang telah bersusah payah melahirkan kita, membesarkan dan mengasuh kita sejak kecil. Setiap orang muslimharus berlaku hormat terhadap orang-orang muslim yang sudah lanjut usia/ orang tua, orang tua yang paling dekat dari kita adalah orang tua kita yaitu ibu bapak. Karenanya berlaku, sopan, hormat, dan memuliakannya adalah merupakan kewajiban yang tidak dapat ditawar-tawar.

Sikap lemah lembut, ramah, dan patuh kepada ibu dan bapaknya adalah 
satu bukti bahwa si anak memiliki rasa terima kasih dan sebagai bahwa dia adalah anak yang shaleh/shalehah. Kemudian dapat disamakan juga dengan kedudukan orang tua kita yaitu saudara-saudara bapak/ibu, mertua, bapak angkat dan lain-lain. Maka kepada mereka juga kita pun harus hormat dan bersikap ramah.

Islam senantiasa mengajarkan kita untuk berbuat baik kepada orang tua dan orang yang lebih tua,menghargai dan menghormatinya . Menghormati mereka dengan sepenuh hati dan senantiasa mengikuti nasihat mereka dalam kebaikan, mencontoh tingkah laku mereka yang baik dan menjadikannya pelajaraan, tidak berkata kasar pada mereka dan menjaga perasaannya walaupun ia berkata tidak baik, senantiasa mendoakan terutama jika mereka adalah orang tua atau saudara kita. 


\section{KESIMPULAN}

Secara garis besar pergaulan itu dapat dilihat dari beberapa lapisan, diantanya yaitu kepada sosok yang usianya lebih muda dan lebih tua. Pergaulan dan persahabatan yang baik tidak sampai putus karena permasalahan yang tidak prinsip dan sepele atau karena informasi negatif yang belum jelas kebenarannya terhadap sahabat kita

Mari kita menjaga akhlak dalam kehidupan agar dapat mewujudkan komunikasi yang baik, dalam makan kita diharuskan mengikuti cara-cara makan yang dicontohkan rasulullah, dalam islam kita diwajibkan menutup aurat dengan baik sesuai Al-Qur'an dan Al- Hadist. 
http://rangga-bachdar.blogspot.co.id/2012/05/akhlak-pergaulan-dalamislam.html,diakses pada 13 september http://ekokhan.wordprees.com/2008/10/24/pergaulan-dalam-islam/,diakses pada 13 september 2015 http://harakatuna.wordpress.com/2008/10/27/aturan-pergaulan-pria-dan-wanitamenurut-islam/,diakses pada 14 september 2015 http://www.scribd.com/doc/23777988/pergaulan-dalam-padangan-islam, diakses pada 14 september 2015 Arsyam, M., Jumliadi, M. H., \& Alwi, A. M. S. (2020). PEMBELAJARAN DIRUMAH DALAM LINGKUNGAN KELUARGA DI TENGAH PANDEMI CIVID 19. Nurfatimah, N., Jumliadi, M. H., \& Abu, A. (2020). Land, Water, and Develoment in Marioriwawo District.

Handaya, Ben. 2002. Etiket dan Pergaulan. Yogyakarta: Kanisius. http://assyafieq.blogspot.com/2010/11/etika-pergaulan-remaja-dalampandangan.html http://dian-pergaulanbebas.blogspot.com/ Ya'qub, H. (1985). Etika Islam: Pembinaann Akhlaqulkarimmah(suatu pengantar). Bandung: Diponegoro 